\title{
The industrial city and its structural changes in local plans on the example of Ruda
}

\author{
Śląska, Poland
}

\author{
Kamil Rysz ${ }^{1}$, Monika Janiszek ${ }^{2}$ \\ ${ }^{1}$ Department of Spatial Economics, University of Economics in Katowice, 1 Maja Str. 50, 40-287 Katowice, Poland \\ ${ }^{2}$ Department of Strategic and Regional Sciences, University of Economics in Katowice, 1 Maja Str. 50, 40-287 Katowice, Poland
}

E-mail address (corresponding author): kamilrysz@interia.pl

\begin{abstract}
In the modern world, the subject of spatial planning is being increasingly raised by residents of municipalities - mainly because of the lack of a direct influence on the process of local development and aesthetics of the surroundings. Today, the primary objective of spatial planning is not only to form a proper connection between function and space but also to balance public and private interests. Constantly developed geographic spatial information systems allow not only for easy navigation around the city, but more importantly for more advanced analyses, such as the recognition of the current trends in estate development, communication systems, changes in agricultural and forest areas. The main objective of the research is to define functional-spatial links determined by social-economic needs reflected in local plans and to verify the similarities between local plans, that were drawn up in three different periods (PRL, the transition period, and in accordance with nowadays applicable laws), how the changing economic, social goals and current needs of the city affected the continuation of the adopted solutions. The study shows that despite changes in the law and abandoning the idea of industrial city, in which the landscape is dominated by blast furnaces and mine shafts, the basic trend has been maintained and local plans prepared in subsequent years form a continuum, and despite the different scales of development are closely linked. At the same time it has been shown that modern GIS tools enable verification of the continuity of spatial policy of the municipality.
\end{abstract}

KEY WORDS: spatial planning, Cross tabulation, urban planning, spatial analysis, GIS systems

\section{Introduction}

The management of space depends on local policy, and also increasingly on the preferences of the local community influencing the direction of development of a territorial unit, and the aesthetics of the surrounding space. The purpose of this article is to determine the possibility of using GIS tools to examine the relationship between the three local spatial development plans of the city of Ruda Śląska: the peak period of Polish People's Republic (PPR), a plan drawn up at the end of the PPR (and the beginning of transformation) and current plan - prepared in compliance with applicable regulations - illustrating the different urban concepts made in various ways. A two-stage comparison was prepared: quantitative and spatial with the use of cross-tabulation. Studies conducted in such way will help to determine whether further documents radically alter the spatial structure, or continue to earlier solutions.

\section{Research methodology}

The first stage of the study consisted of standardization of input data, and it was firstly initiated by scanning and vectorization of local plans of 1979 and 1994 to the ESRI SHP format corresponding to the digital data for 2006 was done. The next step was to import the data into IDRISI Taiga Edition by Clark Labs and reclassification Land Development Plans (LDP) to the general groups, so that it would be made possible to compare data using Cross Tabmodule. This module allows you to perform spatial analyzes of two (or three) raster maps, the result of which is a cross 
table that indicates the direction of change, and the coefficient Kappa determining their mutual correlation (value interpretation from 0 to 1 the closer to 1 the maps are the more similar, and 1 means that the maps are the same) (EASTMAN, 2009).

Simultaneously with the spatial analysis, a quantitative analysis was carried out, i.e. determination of the percentage of space in the foreground that has a specific purpose to define the character of the city. It should be emphasized that due to the differences in detail between specific plans, in order to carry out a quantitative analysis, a generalization of individual precipitates into general groups was conducted, which contain areas about the same or a comparable role.

\section{Characteristics of the test area}

Ruda Śląska, is less than a 60-year-old city area of approximately $77.7 \mathrm{~km}^{2}$, located in the central part of Silesian voivodeship and Katowice conurbation. The city stands out as a product of calculated propaganda of success $50 \mathrm{~s}$, where megalomania of the ruling went beyond the absurd, in effect, bringing to the life of one of the largest and most diverse city like structures (KOSTOŃ, 2009). Since January 2006, it consists of 11 districts that had historically been developed as separate villages.

According to physico-geographical division by KoNDRACKI (2009) Ruda Śląska is located on the Katowice Plateau, and geomorphicaly on the Bytom - Katowice Plateau (GilewsKA, 1972). Bordering in the north with Bytom and Zabrze, in the north-east with Świętochłowice, east with Chorzów and Katowice, and on the south and south-west with Mikołów and Gierałtowice. In the XX century it was a strong center of heavy industry based on coal mining and steel industry. Nowadays, it's hard to spot smoking steelworks chimneys, and with further reforms of the mining industry also mineshafts are disappearing from the landscape. Changing the economic structure of the city and moving away from the traditional industrial economy is also reflected in the city's development strategy for the years 2014-2030, which describes the vision of Ruda Śląska as the city of districts that is not divided and is good for living, work and leisure (STRATEGIA ..., 2014).

A mark on the current structure of the city was made by system of Polish People's Republic planned economy, which recognized the mining industry as most important (SULIK, 1970; SZAFLIK, 1970), which since the 50's to late 80's of XX century determined the city planning goals. With the creation of new jobs increased demand for housing stock due to the influx of people from other parts of the country, that was to be solved with the industrialized construction of large panel buildings. Basic planning issue, was to connect in one urban organism - ancient villages and towns forming a city, which is why they were treated in a comprehensive way to create zoning plans for the whole city, not just from selected areas.

\section{Data}

In the legal system, the municipality is the basis of local governance and the basic cell in planning system. As a result, it is the one, and not the other entities of public authority, to manage space. Only it's planning rules have a binding force and put landowners under legal constrains. No other unit possesses such rights, especially the government administration. Voivodeship planning is reduced to the role of shaping spatial policy in the region and a link between the community's spatial planning and spatial policy of the state. In turn, the districts are merely subregional in spatial planning of voivodeships (NIEWIADOMSKI, 2003).

Due to the nature and purpose of this study, particular attention was dedicated to the graphical part of the local plan, rather than text. As is well known a figure is an integral part of legal act and has binding force, while valid in a range stated in the said act. As NIEWIADOMSKI (2003) writes the legal power of the plan drawing in such degree is understandable. Drawing as a graphic symbol cannot bind directly, because it does not meet the legal standard requirements with its classic structure: a hypothesis, disposition, sanction. It requires, therefore, translation into legal norm, only then can it have legally binding force (NIEWIADOMSKI, 2003).

Plan 1979 was approved January 15, 1979 year by the Voivodalship National Council in Katowice pursuant to Resolution No. XVIII/64/79 on the approval of the local spatial development plans, general settlement assembly cities and municipalities. The above act shows that Ruda Śląska is only part of a large urban development, which predicts the city's area 7790.0 hectares inhabited by 120 thousand people. Local General Plan of Cities Assembly of Urban Spatial Development Upper Silesian Industrial Region, which includes Ruda Śląska establishes the prospect for 1990:

1) the basic functions of the city: the new service center level 2B - Mass Entertainment Center with the regional scope of influence, industrial and residential functions, 
2) four-level hierarchy of service centers in the city (center services unique to the center of mass entertainment, urban center of the third kind, the district centers in each of five structural units and centers in housing estates).

Data in Figure 1 shows that most, because nearly $50 \%$ of the city area, is designed for greenery planting (not including the areas of services with accompanying plants - 3.97\%).
Areas designed for traffic cover a comparable surface area to industrial areas, and the areas of housing and services account for about $25 \%$. Only a small portion of the city's area is designed for water supply devices (including water bodies, water courses) and power equipment. Such a state of affairs comes from the fact that it is a general plan drawn up at a scale of 1:10 000, which makes it difficult to show detail.

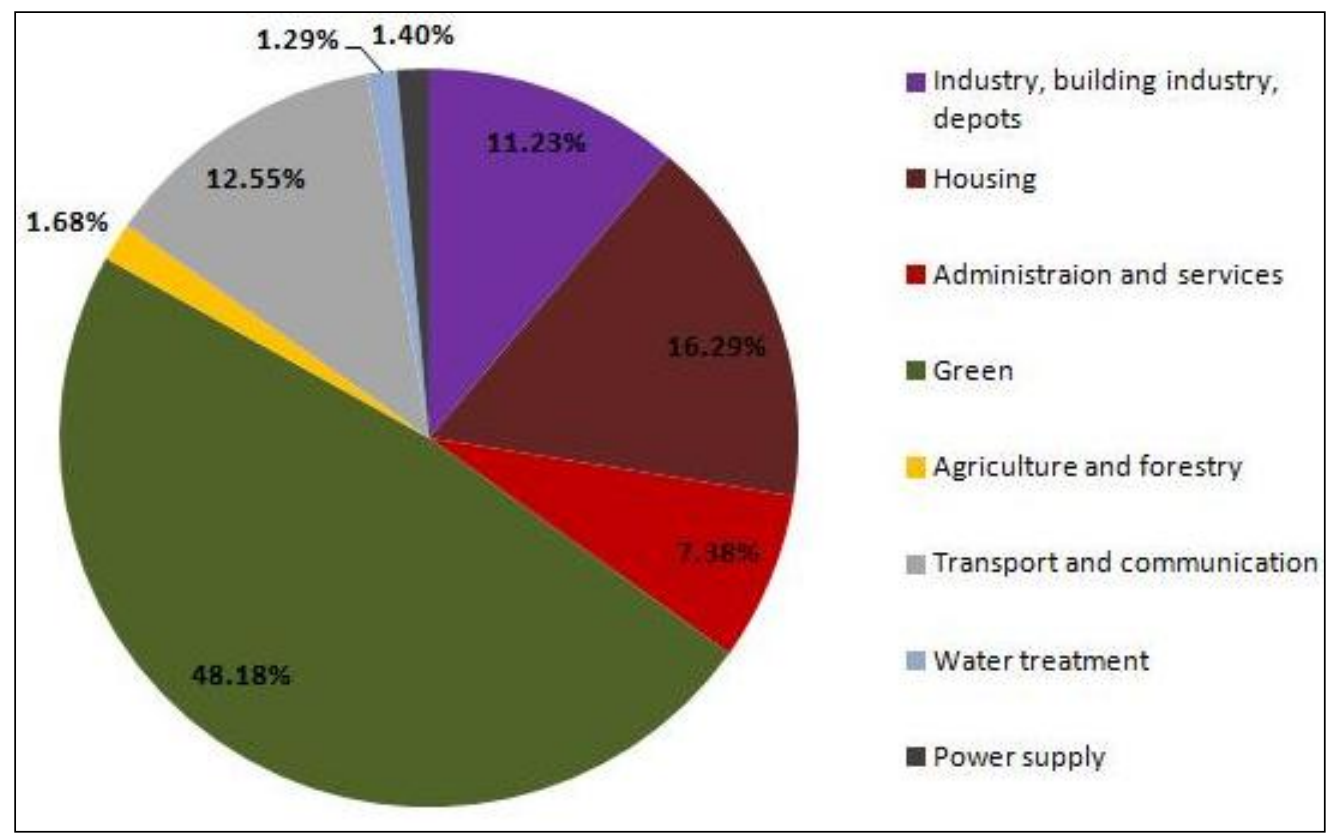

Fig. 1. Purpose of land by the Land Development Plan 1979 divided into general groups

The Substantive (Factual) basis for planning solutions for the local development plan from 1994 are the assumptions for General Spatial Plan of the city of Ruda Śląska. Adopted by the Municipal National Council of 26 April 1990 (Resolution No. 65/XV/90) developed subsequently in the concept plan initially acceptable to the new local government of the city (after the elections in 1990) and later includes the result obligatory public consultation carried in accordance with the requirements of the law on spatial planning. The plan was made for the whole city of Ruda Śląska within its administrative boundaries as of 1990 and was approved by the city council in Ruda Śląska No. 35/VII/1994 of 25 November 1994. The main objectives of the Ruda Śląska development is to enhance the quality of citizens life and on the basis of trends, the city functions were determined in 2020 perspective as follows:

1) industrial center on regional and national level,

2) local residential and service center,

3) a major communication junction of regional importance.

The plan also sets out the general directions of spatial development and shaping of the functional structure of the city, mainly through moderate growth characterized by a slight increase in the number of inhabitants and the limited development of invested areas.

Figure 2 shows that the dominant form of land use is greenery (38.45\%), second leading form of use that takes up $24.32 \%$ of the city - are residential areas. Nearly two times greater surface area than the land the building industry and warehouses. Twice the surface area in relation to the area of services $(7.20 \%)$, as much as $14.74 \%$ involves communication services. The smallest footprint in terms of destination is covered by water treatment plants (2.04\%), areas used for agriculture $(1.07 \%)$ and power equipment $(0.23 \%)$. The large size of the share of the communication area is probably due to detailed plan drawing - scale of 1: 5 000, which largely enabled drawing not only transit roads but also local ones. The small size of the share of agriculture arises from the position of the city - center of the Upper Silesian Industrial Region. Areas of water supply and discharge Bytomka River is not included, because it had been excluded from the boundaries of the study. 


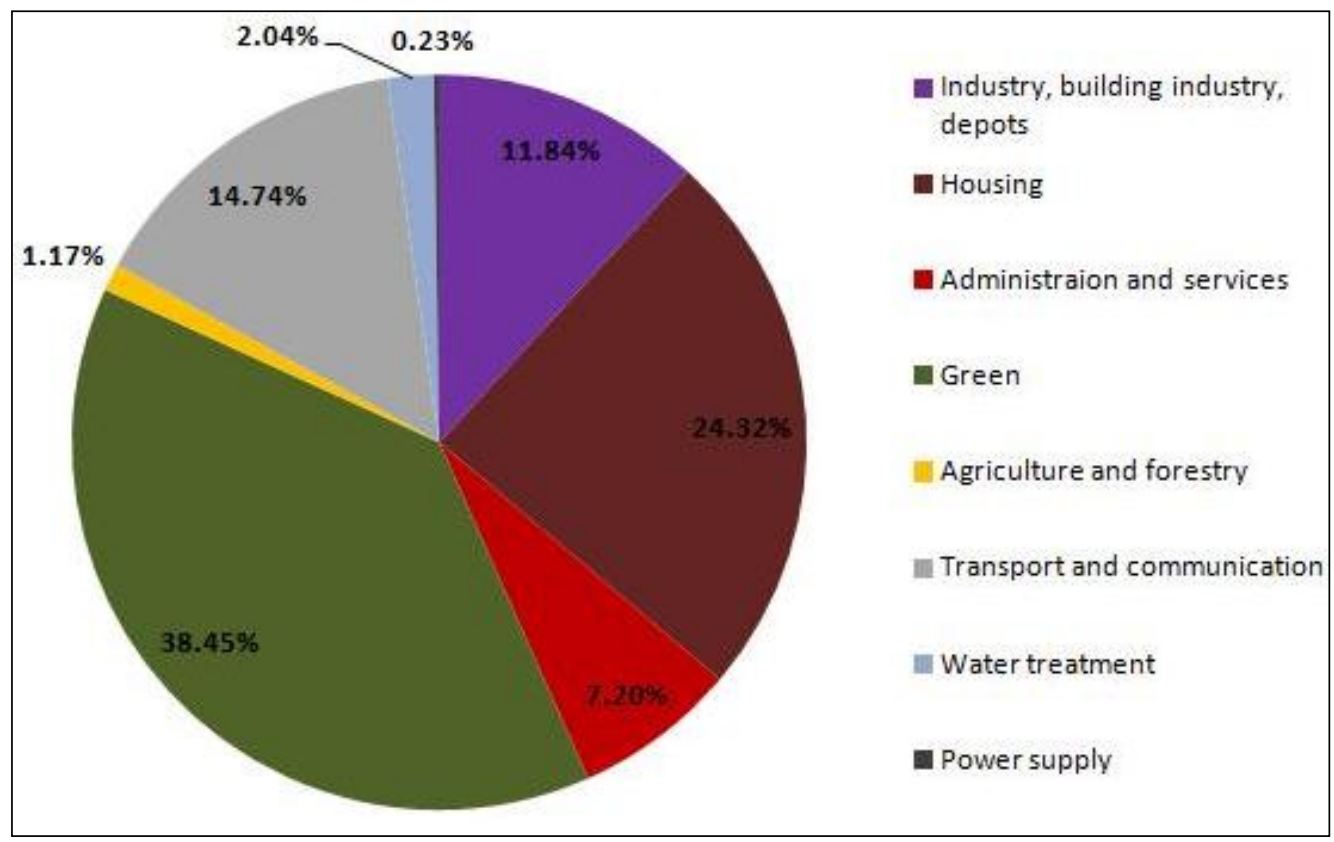

Fig. 2. Purpose of land by the Land Development Plan 1994 divided into general groups

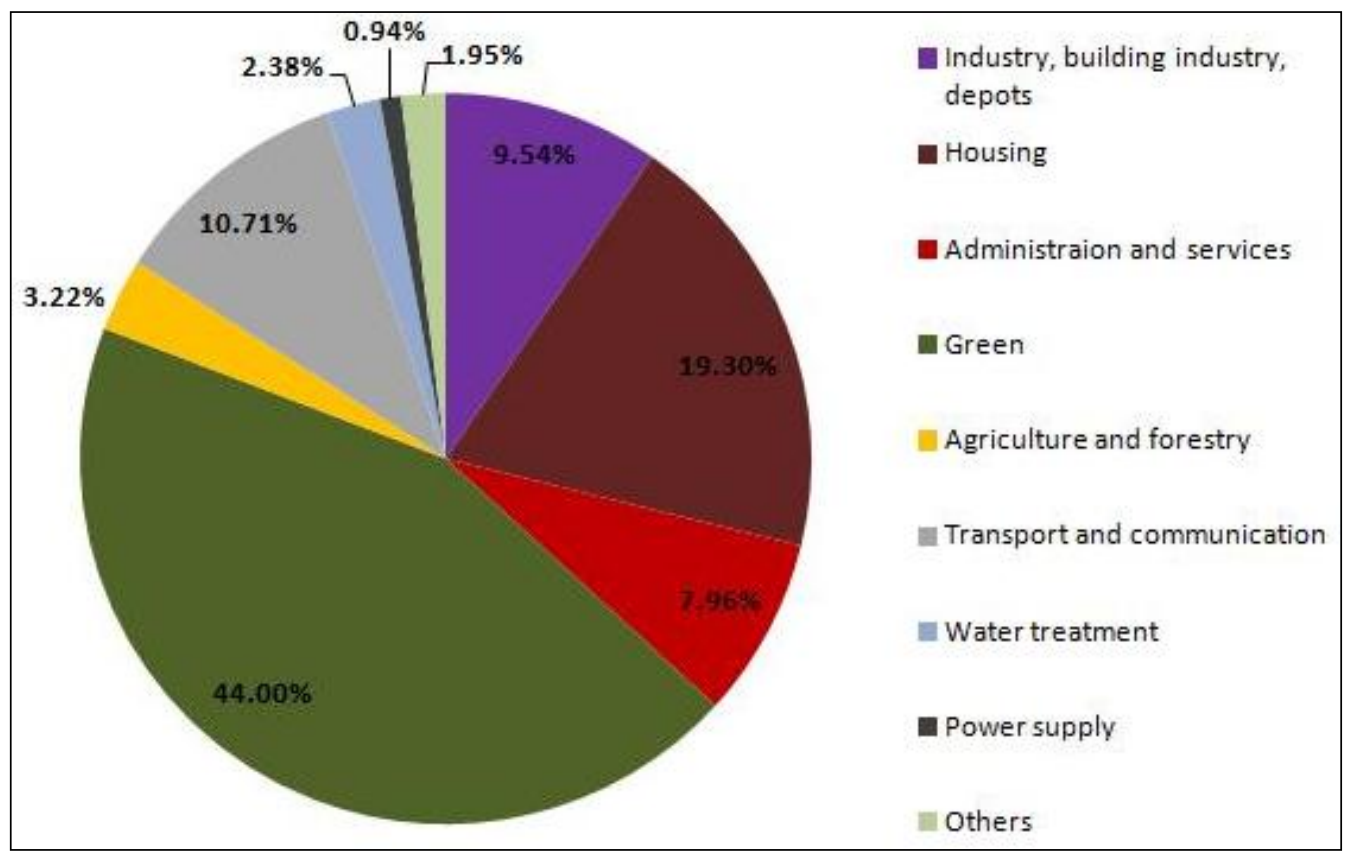

Fig. 3. Purpose of land by the Land Development Plan 2006 divided into general groups

The history of the 2006 plan starts on 11 December 2003, when the City Council made the resolution No. 375/XVII/2003 on accession to the preparing of local spatial development plan of the city Ruda Śląska. Work on drawing of the plan began in early 2004, after emerging in the way of tender, and was adopted in 2006 (Resolution 1066/LXI/2006). It should be stressed that this plan has been drawn up in digital form on the basic map scale of 1: 1000 reduced to 1: 2000 , and is more detailed than the two previously discussed.
The data analysis (Fig. 3) shows that less than $10 \%$ of the city area is to be adapted as industrial, which means two times less than the areas for which the primary purpose is residential development. When it comes to service development areas allocated for this purpose they take up 7.96\% of the municipality.

The dominant purpose are green areas, which in the current plan occupy $44 \%$. As in previous years, a small part of the area, only $3.22 \%$, is designated for agricultural use. Communication and transportation $-10.71 \%$ that is almost 5 times more than the area allocated for water 
sources and waste disposal (water treatment category) (2.38\%). Areas where the device was located for energy plants represent $0.94 \%$. With this plan, there is a group of "other" which includes such items as land facilities and telecommunications equipment, closed areas and areas of infrastructure facilities. It occupies $1.95 \%$ of the municipality.

\section{Analysis of changes in local spatial development plans in the city of Ruda Śląska}

Coal mining within the city of Ruda Śląska has a significant impact on changes in the terrain and the location of some facilities, as a result regulated riverbeds, roads and railway lines are needed, which will undoubtedly affect the analysis of changes in spatial context.
Based on the data presented in Figure 4 one can conclude that the plan from 1994 in comparison to other years emphasizes the purpose of land for industry, construction and warehouses, housing also communication. At the time of preparing this plan significant increase in the number of population in the city - in 1990 and 1991 the city's population exceeded 170 thousand people. So it is understandable that significant land for housing development was designated. At the same time, this plan is based on economic assumptions of late $80 \mathrm{~s}$, hence a considerable amount of land reserved for industrial development. This plan also shows a significant reduction in the number of green areas. At the same time 1994 plan acknowledges such areas as industrial parks and residential parks, which together cover an area of $3.91 \%$ of the area of the city, and were not included in the "green area".

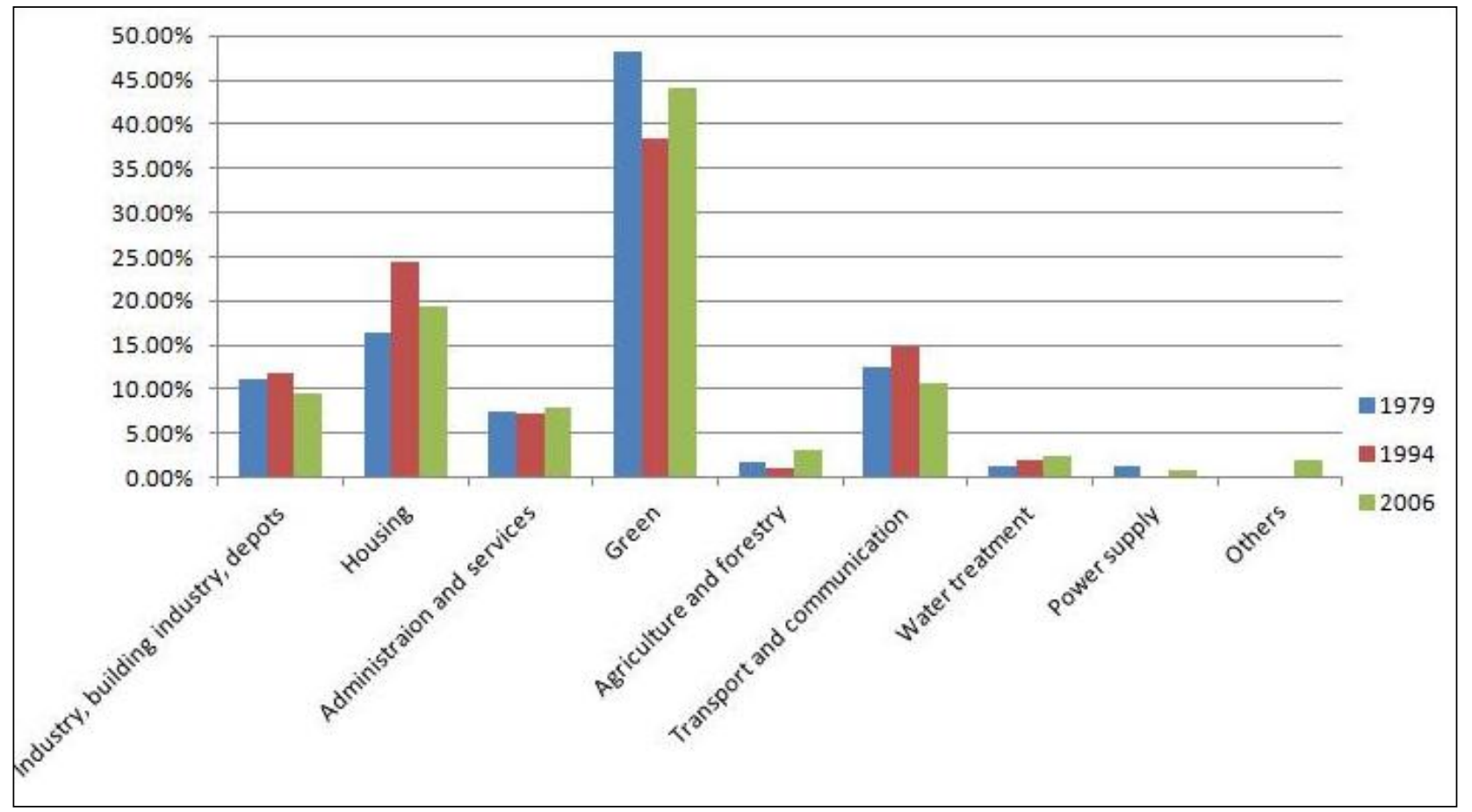

Fig. 4. Comparison of destination areas in the Land Development Plan according to general groups

In the case of the 2006 plan, there is a group of "other" composed mainly of closed areas that were in the Polish State Railways designation. In previous plans, railway lines were part of the group "communication and transport". It should be noted that the quantitative comparison of land for communication is not very meaningful, due to the fact that the plans of 1979 and 1994 are plans drawn up classically, which means using a paper sheet in scale - 1:10 000 and 1: 5000, as well as mathematical drawing pencils, ballpen, pens and other traditional tools. These plans also force other normalization parameters. This results in numerous glitches, especially with regard to the width of the road dividing lines for the map of 1979 is approximately 60-70 meters long and approximately 30-40 meters for a map from 1994, which is the size incomparably greater than the average 25-30 meters for the plan in 2006. Of course, the older plans do not take into account a number of local roads and establish only the main transport corridors. The detail can be mentioned only in the case of the plan from 2006, which takes into account even the smallest streets and lanes. Thus the reduction of the amount of land marked for communication has 
cause in the detailed and precise drawing of the latest development plan.

Based on each of the three local zoning plans three maps of general groups were generated. This procedure allowed the use of cross-tabulation and determination of compliance Kappa index indicates the extent to which the maps are similar.

Using the module CrossTab from program Idrisi Taiga transition matrix is obtained and Kappa index calculated. The following comparison was done:

1) Cross-tab data from 1979 and 1994 respectively,

2) Cross-tab data from 1994 and 2006,

3) Cross-tab data from the 1979 and 2006 years.

It should be noted that the matrices represents the quantity of cells, not the actual surface area between groups. Individual general groups assigned to the corresponding integers, which substantially increases the transparency of the test results. Adopted solution is shown in Table 1.

Tab. 1. General groups categorization

\begin{tabular}{|c|c|}
\hline Category & General group \\
\hline 1 & Industry, building industry, depots \\
\hline 2 & Housing \\
\hline 3 & Administraion and services \\
\hline 4 & Agriculture and forestry \\
\hline 5 & Transport and communication \\
\hline 6 & Water treatment \\
\hline 7 & Power supply \\
\hline 8 & Others \\
\hline 9 & \\
\hline
\end{tabular}

Tab. 2. Matrix transition to map groups overall, 1979 and 1994

\begin{tabular}{|c|c|c|c|c|c|c|c|c|c|}
\hline 19941979 & 1 & 2 & 3 & 4 & 5 & 6 & 7 & 8 & $\begin{array}{l}\text { Index } \\
\text { Kappa }\end{array}$ \\
\hline 1 & 33225 & 244 & 513 & 15426 & 2494 & 3394 & 107 & 1942 & 0.5552 \\
\hline 2 & 2869 & 58088 & 11942 & 32388 & 3430 & 8656 & 229 & 158 & 0.4499 \\
\hline 3 & 803 & 3284 & 10984 & 16868 & 48 & 2901 & 0 & 0 & 0.2894 \\
\hline 4 & 10486 & 7970 & 7209 & 137270 & 1797 & 14059 & 3743 & 3259 & 0.6578 \\
\hline 5 & 127 & 751 & 2275 & 2200 & 0 & 341 & 0 & 75 & -0.0082 \\
\hline 6 & 4526 & 8324 & 2646 & 23966 & 355 & 30719 & 345 & 452 & 0.3935 \\
\hline 7 & 2103 & 162 & 152 & 4801 & 0 & 505 & 1810 & 347 & 0.1781 \\
\hline 8 & 247 & 88 & 0 & 93 & 0 & 159 & 0 & 543 & 0.477 \\
\hline $\begin{array}{l}\text { Index } \\
\text { Kappa }\end{array}$ & 0.5872 & 0.7009 & 0.2823 & 0.4942 & -0.0058 & 0.4673 & 0.2833 & 0.0791 & $\begin{array}{r}\text { total } \\
\mathbf{0 . 6 8 4 7}\end{array}$ \\
\hline
\end{tabular}

Tab. 3. Matrix of transition to map groups of the general 1994 and 2006

\begin{tabular}{|c|c|c|c|c|c|c|c|c|c|}
\hline $2006^{1994}$ & 1 & 2 & 3 & 4 & 5 & 6 & 7 & 8 & $\begin{array}{l}\text { Index } \\
\text { Kappa }\end{array}$ \\
\hline 1 & 31575 & 1087 & 1461 & 5515 & 185 & 4691 & 992 & 745 & 0.6634 \\
\hline 2 & 1702 & 67691 & 4769 & 9119 & 2147 & 7801 & 250 & 29 & 0.687 \\
\hline 3 & 6606 & 9567 & 8463 & 8111 & 224 & 3765 & 1833 & 1 & 0.1911 \\
\hline 4 & 9002 & 16374 & 15979 & 147962 & 1086 & 19354 & 3153 & 129 & 0.6239 \\
\hline 5 & 1741 & 7733 & 504 & 2242 & 1595 & 1046 & 745 & 1 & 0.097 \\
\hline 6 & 3155 & 14171 & 2205 & 5319 & 389 & 26430 & 137 & 39 & 0.4717 \\
\hline 7 & 964 & 208 & 1298 & 5777 & 40 & 320 & 2768 & 0 & 0.2327 \\
\hline 8 & 2440 & 108 & 56 & 1473 & 0 & 337 & 0 & 160 & 0.0339 \\
\hline 9 & 160 & 804 & 153 & 572 & 103 & 7635 & 1 & 26 & 0 \\
\hline $\begin{array}{l}\text { Index } \\
\text { Kappa }\end{array}$ & 0.5288 & 0.531 & 0.2122 & 0.7395 & 0.265 & 0.3358 & 0.2718 & 0.1376 & $\begin{array}{r}\text { total } \\
0.7069\end{array}$ \\
\hline
\end{tabular}

The data presented in Table 2 reflect the results carried out cross-tabs, and the column represent codes map of 1979, and the lines - 1994. The table shows that the greatest transformations, $100 \%$ were areas of agriculture and forestry, which on the map 1994 are represented quite in different categories than in 1979. Further in terms of the biggest change/transformations are areas of energy, in 1994 only approximately 8\% did not undergo conversion. Areas of water treatment, as well as areas of administration and services have also undergone significant transformation. The smallest 
changes when it comes to zoning, occurred in the case of areas of housing, industry, construction and warehouses, also green and communication. The overall index of similarity is 0.6847 , should be interpreted as an agreement between the two maps of around $68.5 \%$. Cramer V index is 0.4887 , which indicates a moderate correlation characteristics.

The data collected in Table 3 reflect the results carried out cross-tab, the columns reflect the codes map of 1994, and the lines - in 2006. The data presented above shows that the biggest changes have been in areas of energy supply and the significant administration and services, agriculture, water treatment, as well as communication. The moderate changes are observed in case for the areas of industry, construction and warehouses, and housing. The smallest changes took place within the green areas, in which map from 2006 are the most similar to that of 1994 . The overall index Kappa is 0.7069 , which means that both maps are similar in nearly $70.7 \%$. Cramer $\mathrm{V}$ ratio is 0.5129 , which is higher by 0.03 relative to the rate determined for the map 1979-1994. This points to a stronger but still moderate correlation characteristics.

The data collected in Table 4 reflect the results carried out cross-tabs, and the column represent codes map of 1994, and the lines - in 2006. Presented in the Table data shows that the biggest changes in the allocation of land occurred in such general groups as agriculture and forestry, water treatment, administration and services, and communication. For other groups: industry, construction, warehouses and storage facilities, housing, greenery and energy similarity is around $60 \%$. General conclusions are that areas of construction industry, warehouses and storage facilities and greenery depicted on the map in 2006 are most similar to these from 1979. Areas of energy supply in 2006, are strongly similar to areas of 1979 - the index Kappa is 0.7262 . General index defined for both maps is 0.6568 , which is similar raster is approx. $65.6 \%$.

Tab. 4. Matrix of transition to map groups overall, 1979 and 2006

\begin{tabular}{|c|r|r|r|r|r|r|r|r|r|}
\hline $2006^{1979}$ & \multicolumn{1}{|c|}{1} & \multicolumn{1}{|c|}{2} & \multicolumn{1}{|c|}{4} & 5 & 6 & 7 & 8 & $\begin{array}{c}\text { Index } \\
\text { Kappa }\end{array}$ \\
\hline 1 & 30467 & 473 & 729 & 9903 & 0 & 3628 & 338 & 708 & 0.6391 \\
\hline 2 & 2392 & 44609 & 8888 & 24822 & 3758 & 7786 & 582 & 675 & 0.4322 \\
\hline 3 & 5091 & 6665 & 7648 & 14443 & 279 & 4335 & 44 & 75 & 0.1685 \\
\hline 4 & 9961 & 11169 & 12170 & 151394 & 2178 & 20938 & 3401 & 1763 & 0.6217 \\
\hline 5 & 199 & 3080 & 3176 & 6048 & 1276 & 1246 & 561 & 21 & 0.0742 \\
\hline 6 & 3558 & 12447 & 2369 & 17440 & 598 & 15012 & 236 & 182 & 0.2434 \\
\hline 7 & 1921 & 372 & 618 & 6317 & 35 & 1110 & 1072 & 22 & 0.0874 \\
\hline 8 & 676 & 62 & 2 & 439 & 0 & 63 & 0 & 3330 & 0.7262 \\
\hline 9 & 119 & 34 & 122 & 2510 & 0 & 6672 & 0 & 0 & 0 \\
\hline $\begin{array}{c}\text { Index } \\
\text { Kappa }\end{array}$ & 0.5389 & 0.5205 & 0.1825 & 0.5537 & 0.1437 & 0.2057 & 0.1623 & 0.4891 & $\mathbf{0 . 6 5 6 8}$ \\
\hline
\end{tabular}

Tab. 5. Array comparative indices Kappa

\begin{tabular}{|c|c|c|c|}
\hline Map & $\begin{array}{c}\text { Unitary Development Plan } \\
1979\end{array}$ & $\begin{array}{c}\text { Unitary Development Plan } \\
1994\end{array}$ & $\begin{array}{c}\text { Unitary Development Plan } \\
2006\end{array}$ \\
\hline $\begin{array}{c}\text { Unitary Development } \\
\text { Plan 1979 }\end{array}$ & 1 & 0.6847 & 0.6568 \\
\hline $\begin{array}{c}\text { Unitary Development } \\
\text { Plan 1994 }\end{array}$ & 0.6847 & 1 & 0.7079 \\
\hline $\begin{array}{c}\text { Unitary Development } \\
\text { Plan 2006 }\end{array}$ & 0.6568 & 0.7079 & 1 \\
\hline
\end{tabular}

Table 5 shows comparative Kappa indices calculated between the different maps. Also previously not mentioned relationship between the LDP a from 1979 and 1994. Presented data in Table 5 shows that each in turn plan is an extension of the previous one. This is evidenced by continuing more or less the same level Kappa indexes and increasing in subsequent years, the number of facilities - 420 on the map 1979, 905 on the map 1994 and 3551 on the map in 2006. It is detailed in terms of clarifying the purpose of each land and not in terms of the creation of a variety of acceptable methods of use. The same can be said of GIS systems that it not only allow 
the comparison of statistical and mathematical, but above all it makes possible to determine the trend of spatial policy in the municipality.

\section{Summary}

The analysis of the local development plans of Ruda Śląska show both the creation pattern of individual plans and urban thought in subsequent years. Plans drawn up in the communist period are generic in names and as whole, expressed by large scale studies and the content of the resolutions. The latest and currently in force plan - details development and the possibility of terrain use, highlights the freedom concerning the management of land (the forefront of property rights, rather than state economic objectives).

Adopted at work testing methods of local development plans have allowed to conclude that there are links between the various plans, while each formed plan is in turn a development and a clarification of the previous one, despite the changes in the economic structure of the city (decrease in the number of employees in industry, restructuring and liquidation of some mines, change the production profile of Steelwork plant "Pokój").

The analysis also shows that each subsequent plan is based on the same backbone of communication, which simply means that the reserved terrain for the construction of new roads has been maintained, and therefore the subsequent implementation of transport corridors does not require additional funding.
On the other hand, a quantitative analysis of the singular precipitate surfaces shows that dominating purpose of the site in Ruda Śląska are green areas, and the greatest human pressure on the environment exerted plan for 1994 by allocating the largest number of land (in comparison to other plans) for industry, housing and communication and transportation. On the other hand, in 2006 the quantity allocated of land for industrial buildings and warehouses does not exceed 9.54\%, so it is less of $1.99 \%$ compared to 1979 and by $2.3 \%$ compared to 1994 , reflecting the departure from industrial to service center (growth areas for administration and services in relation to 1979 and 1994).

\section{References}

Gilewska S. 1972. Wyżyny Śląsko-Małopolskie. [in:] Klimaszewski M. (ed.) Geomorfologia Polski, t. 1. Polska Południowa góry i wyżyny. PWN, Warszawa.

Eastman J.R. 2009. IDRISI Taiga Guide to GIS and Image Processing. Clark Labs Clark Univ., Worcester, MA, USA.

Kondracki J. 2009. Geografia regionalna Polski. PWN, Warszawa.

Kostoń T. 2009. Miasto przemysłowe głębokiej transformacji - w poszukiwaniu urody. [in:] Uroda miasta, Odnowa krajobrazu miejskiego - ular 4. Wydz. Architektury Politech. Śląskiej i Kom. Architektury i Urbanistyki PAN, Gliwice.

Niewiadomski Z. 2003. Planowanie przestrzenne, zarys sytemu.. Wyd. LexisNexis, Warszawa.

Strategia Rozwoju Miasta Ruda Śląska na lata 2014-2030; załącznik do Uchwały nr PR.0007.49.2014 Rady Miasta Ruda Śląska z dnia 27 marca 2014 r.

Sulik A. 1970. Sytuacja gospodarcza, [in:] Szefer A. (ed.) Ruda Śląska, Zarys rozwoju miasta. Wyd. Śląsk, Katowice.

Szaflik J. 1970. Górnictwo węgla kamiennego. Większe zakłady przemysłowe na terenie Rudy Śląskiej [in:] Szefer A. (ed.) Ruda Śląska. Zarys rozwoju miasta. Wyd. Śląsk, Katowice. 